DOI

\title{
РОЗРОБКА ЕНЕРГОЕФЕКТИВНОГО РЕЖИМУ СУШІННЯ ФІТОЕСТРОГЕННОЇ РОСЛИННОЇ СИРОВИНИ
}

Петрова Ж.О., академік УАН, д.т.н., гол.наук.співр., Слободянюк К.С., мол.наук.співр. Інститут технічної теплофізики НАН України, м.Київ, Україна

\begin{abstract}
Анотація. Білкові продукти на основі сої є ідеальним джерелом важливих для організму амінокислот, доповнюють білки зернових $і$ здатні повністю замінити тваринні продукти. Соя - природне джерело рослинних фітоестрогенів. Одним з видів переробки сої є сушіння. В час енергетичних криз, ща зумовлені енерговитратними технологіями та обладнанням виникає необхідність дослідження та подальшої розробки енергоефективних режимів сушіння. В даній статті наявний опис рекомендованих етапів попередньої гігротермічної підготовки сировини до сушіння, щзо дозволяє інактивувати антихарчові компоненти в соєвих бобах. В результаті попередньої гігротермічної обробки відбувається майже повна інактивація інгібітора трипсину, після гігротермічної обробки його лишається всього 4\%. Обгрунтовано доцільність створення соєво - шпинатної суміші та запропоновано енергоефективний режим сушіння фітоестрогенної суміші. Проведені експериментальні дослідження по сушінню соєво-ипинатної композиції при температурах теплоносія $60^{\circ} \mathrm{C}$ та ступеневій зміні температури теплоносія $100 / 60^{\circ} \mathrm{C}$ показали, шуо тривалість сушіння матеріалу в режимі теплоносія $100 / 60^{\circ} \mathrm{C}$ зменшується на $25 \%$ в порівнянні з тривалістю процесу при $60^{\circ} \mathrm{C}$. Результати досліджень впливу температури теплоносія на зміну кислотного числа соєво - шпинатної суміші доводять, щзо при поєднанні сої з каротиновмісною сировиною, шпинатом характер зміни кислотного числа аналогічний характеру цілих соєвих бобів. Встановлено, щзо соєво - шпинатний порошок відновлюється швидше в 2 рази за еталон (сухий молочний білок). В результаті проведених досліджень встановлено, що створення фітоестрогенної суміші з сої та шпинату дозволило зменшити енерговитрати на 20 - $25 \%$ на підготовку сировини до сушіння. На основі проведених досліджень запропоновано теплотехнологію для сушіння фітоестрогенної рослинної сировини.
\end{abstract}

Ключові слова: енергоефективність, сушіння, кислотне число, вологовміст, фітоестрогени.

\section{DEVELOPING OF ENERGY EFFECTIVE DRYING MODE OF FITOESTHROGENIC RAW MATERIAL}

Petrova Zh.O., Academician UAS, Doctor of Engenering., Chief researcher,

Slobodianiuk K.S., Junior researcher

Institute of Technical Thermophysics of the National Academy of Sciences of Ukraine, Kyiv, Ukraine

\begin{abstract}
Soybean protein products are the ideal source of amino acids important for the body, supplementing the proteins of cereals and are able to completely replace animal products. Soya - a natural source of plant phytoestrogens. One type of soy processing is drying. During the energy crises caused by energy-consuming technologies and equipment, there is a need for research and further development of energy-efficient drying regimes. In this article, there is a description of the recommended steps of the preliminary hygrothermal preparation of raw materials for drying, which allows inactivating the anti-food components in soy beans. As a result of the previous hygrothermal treatment almost complete inactivation of the trypsin inhibitor occurs, after the hydro-thermal treatment it remains only 4\%. The expediency of creating a soybean - spinach mixture was substantiated and the energy - efficient drying of phytoestrogenic mixture was proposed. Experimental studies on drying of a soy-spinach composition at temperatures of the coolant-temperature of $60^{\circ} \mathrm{C}$ and a step-by-step change in the temperature of the coolant $100 / 60^{\circ} \mathrm{C}$ (at a temperature of $60^{\circ} \mathrm{C}$ in the middle layer of the material, the temperature of the coolant was reduced from $100{ }^{\circ} \mathrm{C}$ to $60{ }^{\circ} \mathrm{C}$ ) showed that the drying time of the material in the mode of the coolant-temperature $100 / 60^{\circ} \mathrm{C}$ decreases by $25 \%$ compared with the duration of the process at $60^{\circ} \mathrm{C}$. The results of studies on the effect of heat carrier temperature on the change in the acid number of soybean spinach mixture show that, when combined with carotene - containing raw materials, spinach, the nature of the change in the acid number is similar to the nature of whole soybeans. Studies were conducted of restore the resulting soy - spinach powder. It has been established that soy - spinach powder is recovered more than 2 times the standard (dry milk protein). As a result of the research, it was found that the creation of phytoestrogenic mixture of soya and spinach allowed to reduce energy consumption by 20-25\% for the preparation of raw materials for drying. On the basis of the conducted research the heat-technology for drying phytoestrogenic plant material was proposed.

Key words: energy efficiency, drying, acid number, moisture content, phytoestrogens.
\end{abstract}

Наукові праці, Том 83, випуск 1

Scientific Works, Volume 83, Issue 1 
Вступ. У сучасному світі місце та роль України залежить від іiї здатності ефективно реалізувати свої переваги природно - ресурсного потенціалу у світовому розподілу праці та у міжнародній ринковій конкурентній боротьбі. Стратегія розвитку аграрного сектору України має бути спрямована на формування ефективного, ресурсозберігаючого, еколого-безпечного, соціально спрямованого, наукоємного сектору економіки держави, здатного задовольнити потреби внутрішнього ринку та забезпечити провідні позиції на світовому ринку сільськогосподарської продукції та продовольства [1].

У найближчі роки соя може стати найважливішим фактором у харчуванні людей у всьому світі [2]. В Україні в раціоні населення білковий дефіцит становить більше $20 \%$ [3], починаючи з 2000 року соя перетворилася 3 аутсайдера в одну з основних олійних культур. Україна - найбільший виробник сої в Європі та займає 8 місце в світі. Основними експортерами сої є Бразилія, США, Аргентина, Парагвай та Канада. Основними світовими імпортерами сої є Китай та ЄС. Експорт продовжує стрімко розвиватися, через попит імпортерів на сою [4].

Білкові продукти на основі сої є ідеальним джерелом важливих для організму амінокислот, доповнюють білки зернових і здатні повністю замінити тваринні продукти. Відомі більше 50 продуктів переробки сої [2]. Найбільш популярними є такі соєві продукти: соєве борошно, соєвий білковий концентрат, соєві ізоляти, текстурований білок, соєве молоко, м'ясні та молочні аналоги (замінники), соєвий сир тофу.

Фізико - хімічні властивості бобів сої обумовлені особливостями будови і властивостями рослинних клітин і тканин [5]. Соя - природне джерело рослинних фітоестрогенів.

Фітоестрогени є сполуками рослинного походження, які не синтезуються в організмі людини і функціонально імітують естрогени і тому вважається, що вони відіграють значну роль у профілактиці раку, хвороби серця, менопаузи симптоми і остеопороз (Setchell, 1998; Adlercreutz, 2002; Kronenberg \& Fugh-Berman, 2002). Естроген впливає на: ріст і функціонування жіночої і чоловічої статі; репродуктивні тканини; підтримує скелетну і центральну нервові системи; забезпечує кардіопротекторні ефекти в серцево-судинній системі; захищає від раку товстої кишки; сповільнює процеси старіння шкіри (Gruber et al., 2002; Ruggiero i Liki, 2002) [6].

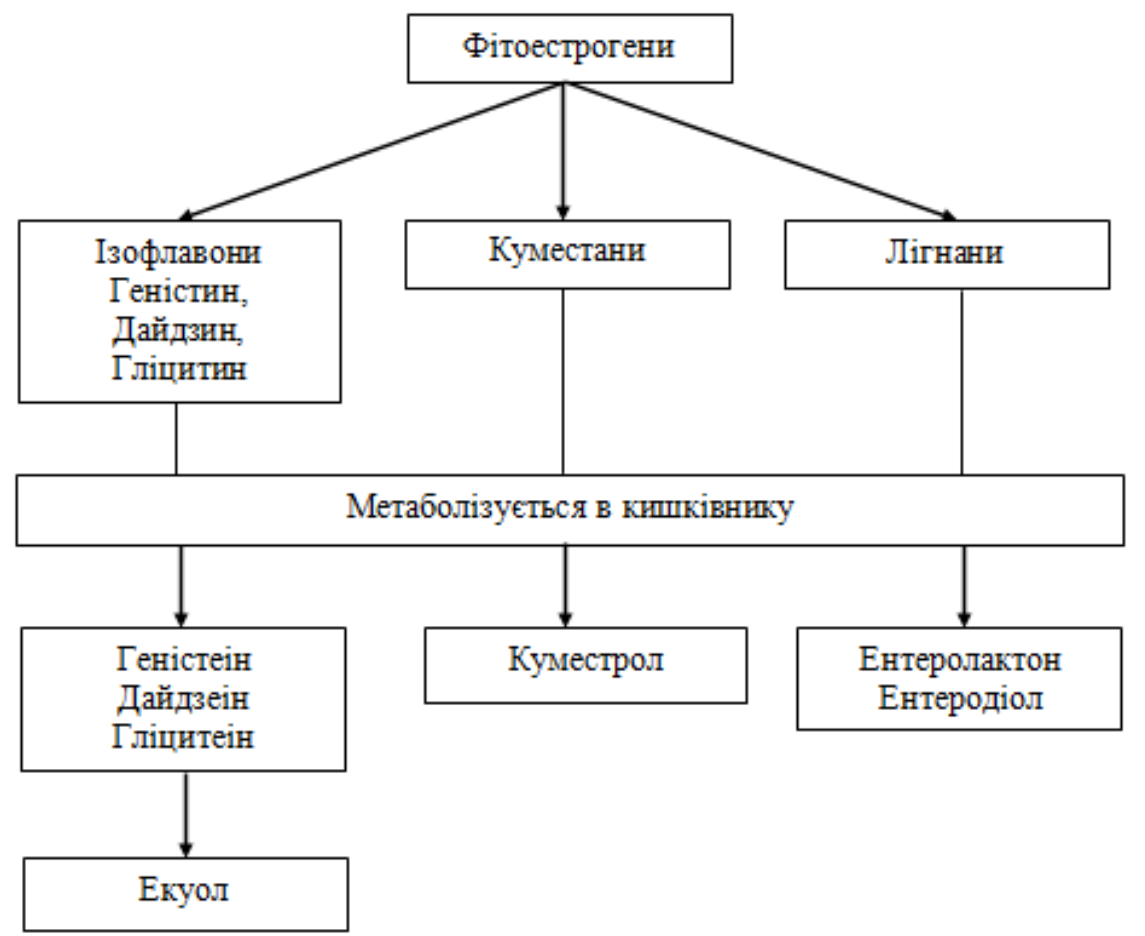

Рис. 1. Класифікація фітоестрогенів

Фітоестрогени поділяються на: ізофлавони, куместани, лігнани (рисунок 1). Найкраще всього вивчені фітоестрогени, які знаходяться в сої - в першу чергу ізофлавони, геністеіни та дайдзеіни.

Соєвий білок характеризується добре збалансованим амінокислотним складом, який майже відповідає балансу ідеального білка. Соєві боби містять від 35 до 45 \% повноцінного білку, 18-25 \% жирів, біологічноактивні речовини та 8 незамінних амінокислот [7]. 
Бразильськими вченими в ході біохімічних досліджень встановлено, що висока кількість сапонінів втрачаються в оболонці сої під час її переробки [8]. Сапоніни мають здатність захищати організм людини від радіаційного впливу, а саме радіонуклідів котрі послаблюють імунну систему [8].

Одним з видів переробки сої є сушіння. Процес сушіння є енерговитратним процесом. На процеси термічного зневоднення в світі витрачається біля 10\% всієї енергії [9]. Отже, виникає необхідність розробки енергоефективної теплотехнології переробки фітоестрогенної сировини на базі попередньо гігротермічно обробленої сої.

Особливістю бобової культури сої є вміст в іiі хімічному складі антихарчових компонентів (інгібітор трипсину). Попередніми дослідженнями в Інституті технічної теплофізики НАН України була розроблена попередня підготовка соєвих бобів до сушіння для нейтралізації антихарчових компонентів [7]. Основними етапами якої були: замочування соєвих бобів, гігротермічна обробка, промивка водою для стабілізації ліпідів, змішування компонентів фітоестрогенної сировини, подрібнення [10].

В результаті попередньої гігротермічної обробки відбувається майже повна інактивація антихарчових компонентів, а саме - інгібітора трипсину. 3 рисунку 2 видно, що після гігротермічної обробки його лишається всього $4 \%$.

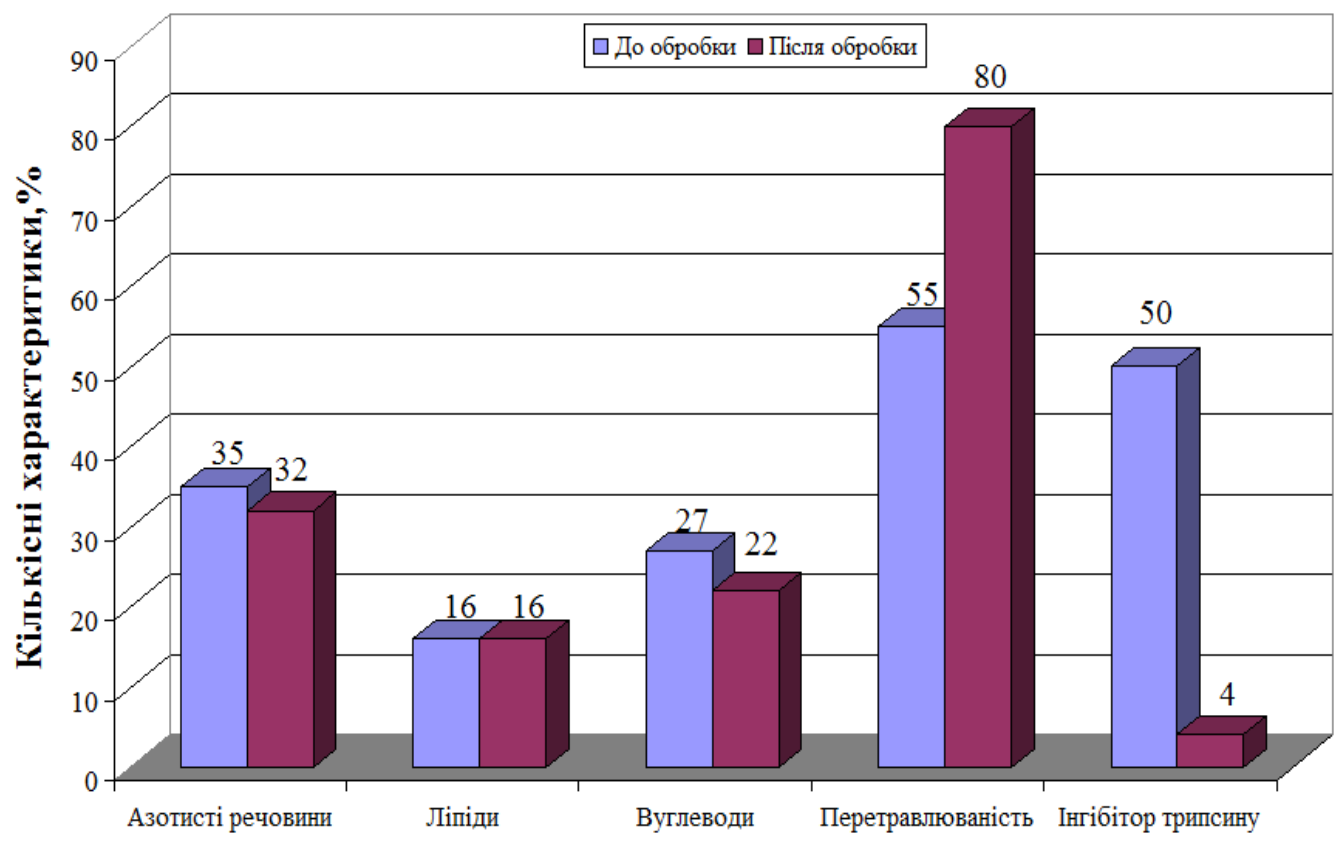

Показники якості соєвих бобів

Рис. 2 - Зміна якісних показників фітоестрогенної сировини до сушіння (гігротермічна обробка сої)

Через високий вміст жиру скорочує термін зберігання подрібненої сої, відбувається окислення жиру яке призводить до руйнування інших поживних компонентів. Для запобігання окислення жирів боби сої поєднували з каротиновмісною сировиною - шпинатом.

Матеріали та методи. Дослідження процесів конвективного сушіння проводили на експериментальному стенді, розробленому в Інституті технічної теплофізики НАН України [11]. Попередньо підготовлену соєво - шпинатну композицію розташовували на сітчастий піддон (100х50 мм) в шар 15 мм на штангу терезів в сушильній камері. Зміну температури на поверхні та в середині об'єму шару матеріалу під час сушіння фіксували за допомогою термопар. Процес сушіння тривав до кінцевого вологовмісту матеріалу $\mathrm{W}^{\mathrm{c}}{ }_{\mathrm{\kappa}}=4 \%$, для подовження строку зберігання висушеної суміші в порошкоподібному стані [12].

Результати досліджень. Під час дослідження кінетики процесу конвективного сушіння важливо дотримуватися температурного режиму та не допускати перегріву матеріалу. Як відомо, каротиноїди руйнуються при взаємодії з киснем, теплом та світлом. Тривале сушіння при температурі $100^{\circ} \mathrm{C}$ призводить до мелаїдінових реакцій $[7,11]$. Сушіння білкововмісної сировини при високих температурах сушильного агенту призводить до повної денатурації білків. Отже, для запобігання цих процесів, а також для збереження біологічно активних речовин, рекомендується сушити білково-каротиновмісні суміші з використанням режимів при яких температура в середньому об'ємі шару матеріалу не перевищуватиме $60 \ldots 70{ }^{\circ} \mathrm{C}$. Тож при розробці енергоефективного режиму сушіння соєво - шпинатної композиції було проведено дослідження задовільного температурного режиму процесу. Були проведені експериментальні дослідження по сушінню соєво- 
шпинатної композиції з початковою вологістю $\mathrm{W}=73,5 \%$ при температурах теплоносія $60^{\circ} \mathrm{C}$ та ступеневій зміні температури теплоносія $100 / 60^{\circ} \mathrm{C}$ ( при наближенні до $60^{\circ} \mathrm{C}$ в середньоб'ємному шарі матеріалу температуру теплоносія знижували зі $100^{\circ} \mathrm{C}$ до $60^{\circ} \mathrm{C}$ ). Результати яких показали, що тривалість сушіння матеріалу в режимі теплоносія $100 / 60^{\circ} \mathrm{C}$ зменшується на $25 \%$ в порівнянні з тривалістю процесу при $60^{\circ} \mathrm{C}$ [13].

Характеристикою кінетики процесу сушіння є число Ребіндера $(R b)$, яке визначає відношення кількості теплоти, витраченої на нагрівання матеріалу та на випаровування значної вологи за нескінченно малий проміжок часу:

$$
R b=b \frac{\bar{c}}{r}=\frac{\bar{c}}{r}\left(\frac{d \bar{t}}{d \bar{W}}\right)
$$

Попередніми дослідженнями [11] білково - каротиновмісної сировини на базі сої та моркви було розраховано та отримано залежність зміни числа Ребіндера від вологовмісту суміші (рисунок 3). Відомо, що число Ребіндера не залежить від швидкості та вологовмісту теплоносія, а визначається тільки тепловим режимом сушіння.

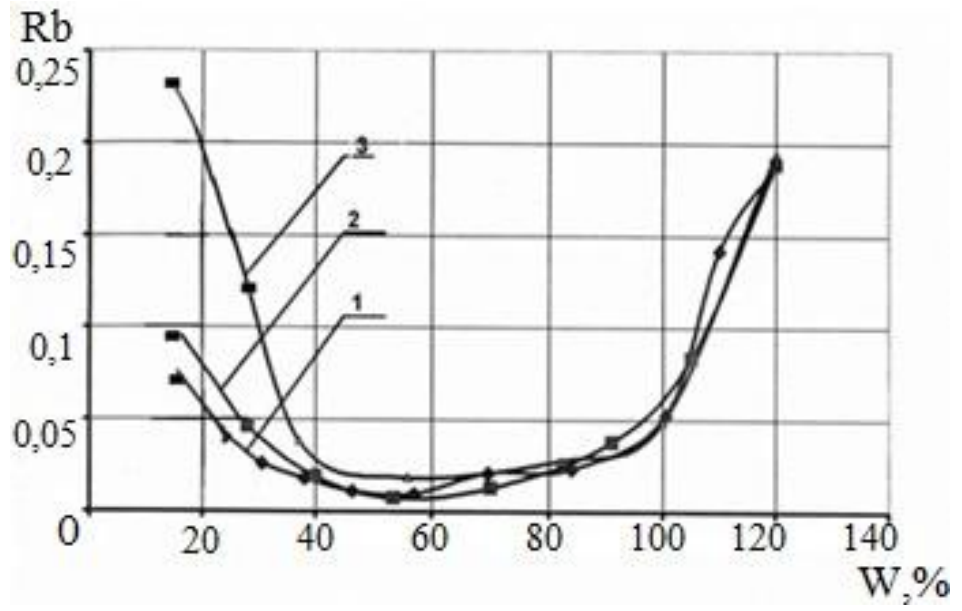

Рис. 3 - Зміна числа Ребіндера в процесі зневоднення соєво-морквяної суміші:

$V=2$ м/с; d=10 г/кг с.п.; гранули розміром $10 \times 10$ х 65 мм; співвідношення сої та моркви 1:1; температура теплоносія $\mathrm{t},{ }^{\circ} \mathrm{C}$ : $1-120,2-100,3-80$.

Проаналізувавши з рисунку 3 криву 2 можна зробити висновок, що після досягнення вологовмісту 5042 \% число $R b$ різко збільшується, а це означає, що більша частина теплоти витрачається не на інтенсивне випаровування вільної та зв'язаної вологи, а на нагрівання матеріалу. Як наслідок, може відбуватися руйнування біологічно активних речовин. Характер зміни числа Ребіндера доводить ефективність використання ступеневих режимів сушіння. Відомо, що під час видалення вологи 3 матеріалу густина теплового потоку зменшується і найбільший мінімум відповідає режиму сушіння $100^{\circ} \mathrm{C}$ [14]. Це ще раз підтверджує потребу використанням ступеневих режимів, що безумовно позитивно впливає на якість кінцевого продукту.

На рисунку 4 (а) зображено залежність вологовмісту від часу і графічно зафіксовано, що ступенева $\left(100 / 60{ }^{\circ} \mathrm{C}\right)$ зміна температури теплоносія (крива 2) дозволяє скоротити час сушіння порівняно 3 режимом $60{ }^{\circ} \mathrm{C}$ (крива 3$)$.

Використання ступеневої зміни температурного режиму призводить до збільшення швидкості сушіння в початковий момент в 2 рази (рисунок 4 (б) ) відносно температурного режиму $60{ }^{\circ} \mathrm{C}$, внаслідок чого час сушіння до кінцевого вологовмісту скорочується на $25 \%$.

Основною характеристикою якості соєво - овочевих композицій є зміна кислотного числа в процесі сушіння. Кислотне число характеризує кількість вільних жирних кислот, що містяться в 1 г жиру, визначається кількістю міліграмів їдкого калію необхідного для їх нейтралізації [15].

Оскільки соя містить високу кількість жиру, це означає, що 4\% є максимально допустимим значенням. Отже, вплив температури теплоносія в процесі сушіння досліджували відповідно до результатів досліджень зміни кислотного числа.

Повторення попередніх досліджень зміни кислотного кисла [16] цілих бобів сої, зафіксувало, що в процесі сушіння від впливу температури теплоносія практично не відбувається зміна кислотного числа, але подрібнена соя має інші характеристики в процесі теплової обробки. 


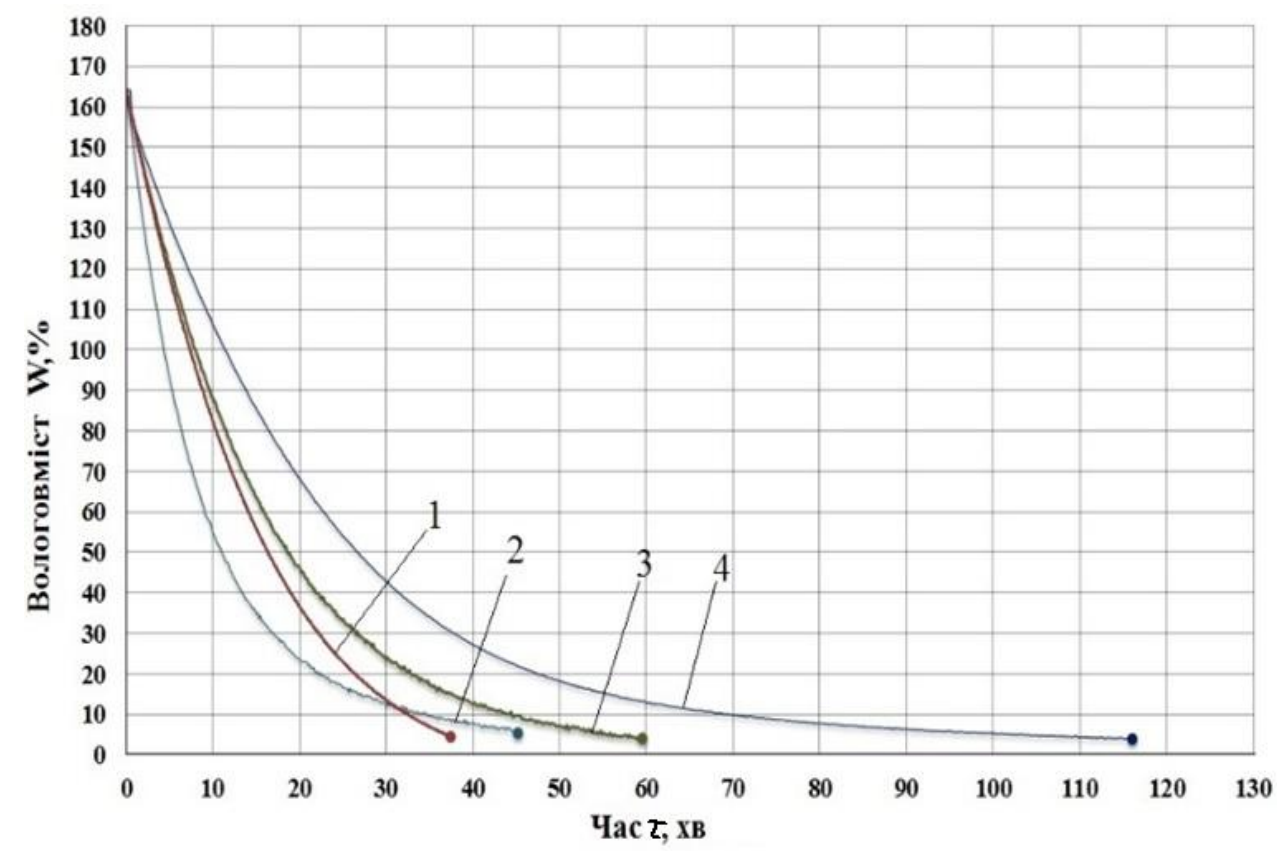

a)

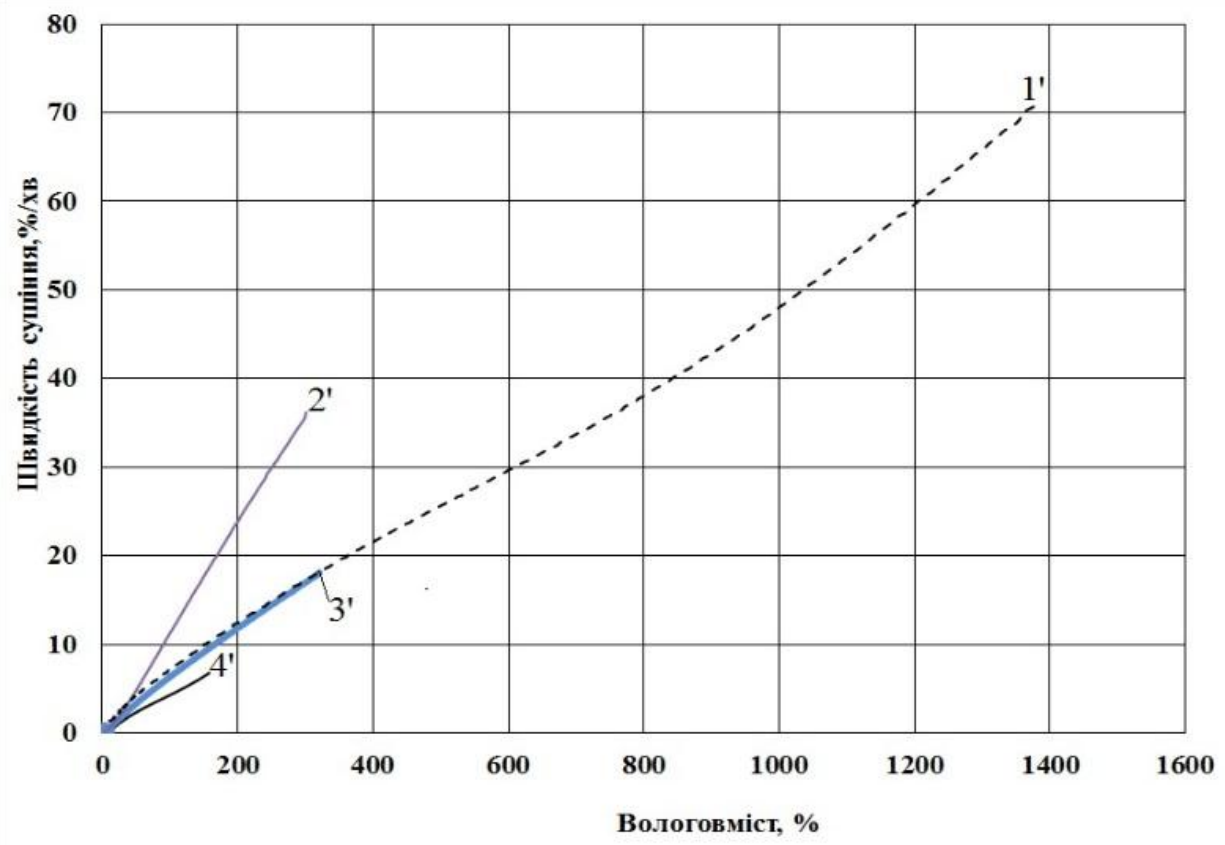

б)

$1,1^{\prime}$ - шпинат при $60{ }^{\circ} \mathrm{C} ; 2,2$ ' - соєво-шпинатна суміш при $100 / 60{ }^{\circ} \mathrm{C}$;

$3,3^{\prime}$ - соєво-шпинатна суміш при $60^{\circ} \mathrm{C} ; 4,4^{\prime}-$ соя при $60^{\circ} \mathrm{C}$.

Рис. 4 - Криві сушіння (а) і швидкості сушіння (б) моносировини та соєво-шпинатної суміші(1:1) при режимних параметрах $v=2,5 \mathrm{M} / \mathrm{c}, \mathrm{d}=10$ г $/$ кг с.п., $\delta=15 \mathrm{~mm} ; \mathrm{W}_{\mathrm{K}}^{\mathrm{c}}=4 \%$ абс. та різних температурах теплоносія.

Цікаві результати отримано 3 нових досліджень на соєво - шпинатній суміші. Як видно 3 рисунку 5 , встановлено, що при поєднанні сої з каротиновмісною сировиною, шпинатом характер зміни кислотного числа аналогічний характеру цілих соєвих бобів і не перевищує максимально допустиме значення. Це дозволило розширити температурний діапазон теплоносія в процесі сушіння і підтвердило ефективність використання ступеневого режиму сушіння $100 / 60^{\circ} \mathrm{C}$. 


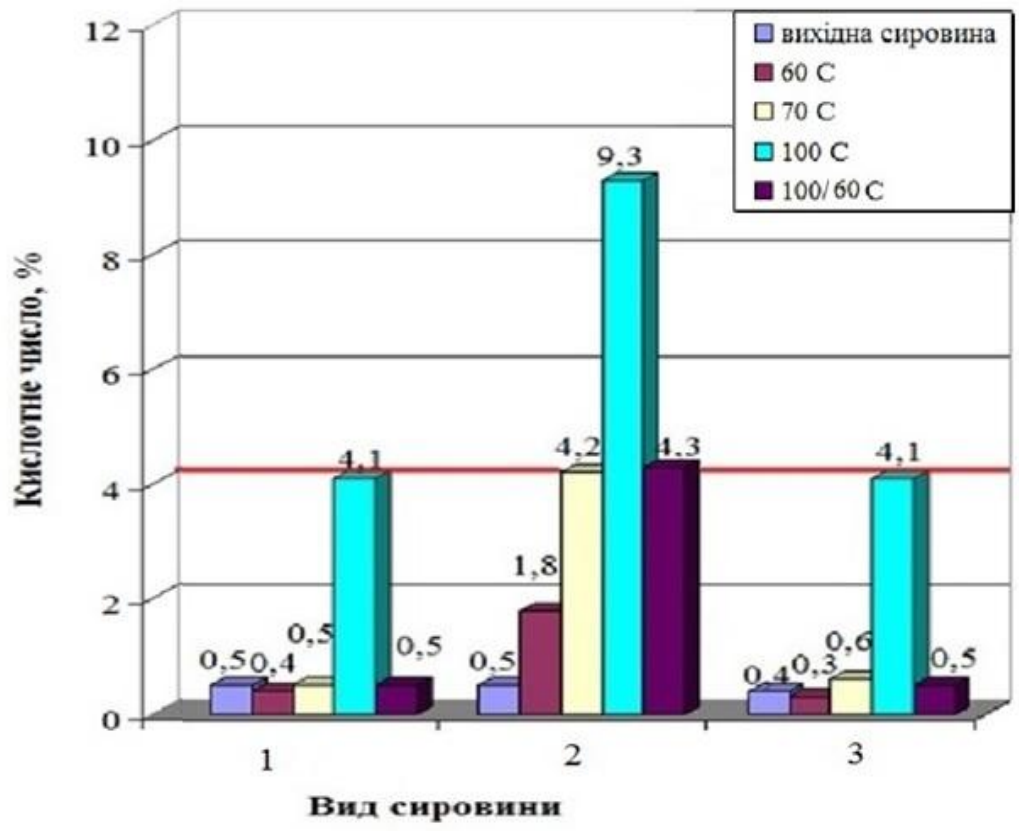

Рис. 5 - Зміна кислотного числа фітоестрогенної сировини в процесі сушіння.

Проводилися дослідження відновлювання отриманого соєво - шпинатного порошку. Оскільки соя - високобілкововмісна сировина, то еталоном порівняння було прийнято сухий молочний білок. Було зафіксовано, що сухий молочний білок відновлюється за 20 секунд, а соєво - шпинатний порошок за 9 секунд.

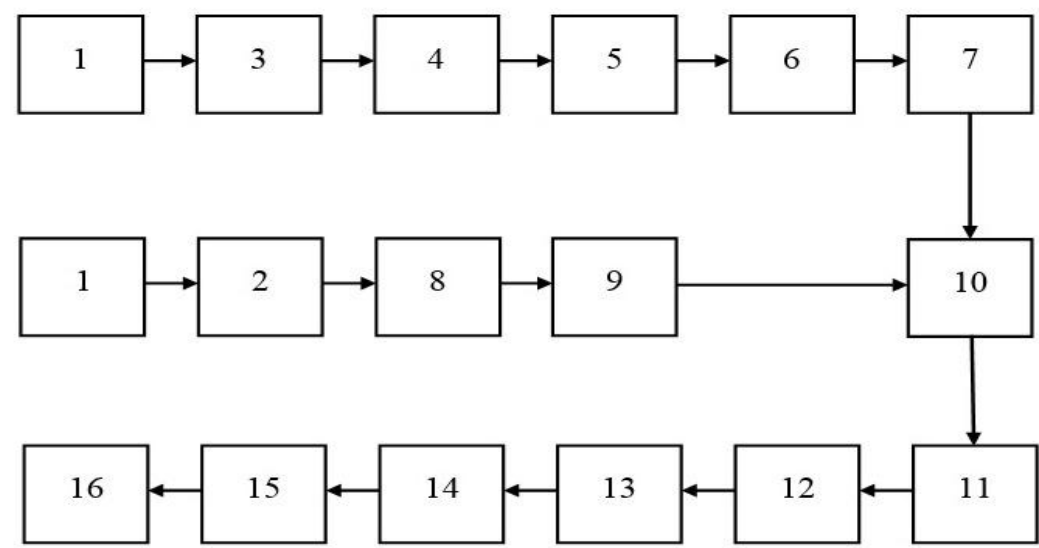

1 - приймання сировини; 2 - мийка сої; 3 - інспекція шпинату; 4 - конвеєр інспекційний; 5 - миття та замочування шпинату; 6 - нарізання шпинату; 7 - дозування шпинату;

8 - дозування сої; 9 - гігротермічна обробка сої; 10 -змішування; 11 - подрібнення; 12 - сушіння; 13 охолодження; 14 - диспергування; 15 -пакування.

Рис.6 - Блок - схема технологічної лінії виробництва харчових порошків 3 фітоестрогенної рослинної сировини

На базі проведених досліджень фітоестрогенних композицій було розроблено технологічну лінію виробництва фітоестрогенних харчових порошків [16], блок - схема якої зображена на рисунку 6.

Соєві боби поступають в бункер - приймальник сировини (1), потім у машину для мийки сої (2) 3 температурою води $18-20{ }^{\circ} \mathrm{C}$. Боби після дозатора (8) подають у варочний котел (9) для гігротермічної обробки сої, яка включає двохстадійну термічну обробку: замочуванння при температурі $50{ }^{\circ} \mathrm{C}$ впродовж 60 хв. після термостатування боби промивають проточною водою, в яку виходять розчинні у воді олігосахариди. Після цього, промиті боби варять протягом 20 хв. для інактивації інгібітора трипсину та уреази.

Ділянка підготовки шпинату складається із бункера - приймальника (1), ділянки для ручної інспекції шпинату (3). Після цього він подається на інспекційний конвеєр (4), де відбувається контроль інспекції 
шпинату. Потім ступає на машину для миття та замочування (5), після чого на ділянку (6) де відбувається його нарізання. Дозатором (7) подається у змішувач (10) фітоестрогенної сировини.

Підготовлені шпинат та боби після бункера-дозатора (7) і після гігротермічної обробки сої (9) змішуються (10) та подають на машину для подрібнення (11). Сформований матеріал рівномірно розподіляють на сушильну поверхню і подають на сушку (12), а потім охолоджують (13) до температури $20^{\circ} \mathrm{C}$.

Висушена сировина поступає на диспергування (14), де подрібнюється до порошкоподібного стану та класифікується в сепараторі (15) до розмірів частинок до 0,16-0,5 мм. Отриманий соєво-цибулевий порошок фасують у крафт-мішки та маркірують (16).

Створення композиційних сумішей дало можливість зменшити енерговитрати на підготовку сировини до сушіння на $20-25 \%$.

Висновки: Дотримання рекомендованих етапів попередньої гігротермічної підготовки сировини до сушіння дозволяє інактивувати антихарчові компоненти в соєвих бобах. Поєднання білкововмісної (сої) 3 каротиновмісною (шпинат) сировиною розширило температурний діапазон зміни кислотного числа в процесі сушіння. Суміш дуже швидко відновлюється, час відновлення - 9 секунд. Використання ступеневого режиму сушіння $100 / 60^{\circ} \mathrm{C}$ дозволяє інтенсифікувати процес сушіння соєво - шпинатної суміші і скоротити час сушіння на 25\%. В результаті проведених досліджень встановлено, що створення фітоестрогенної суміші 3 сої та шпинату дозволило зменшити енерговитрати на $20-25 \%$ на підготовку сировини до сушіння. На основі проведених досліджень запропоновано теплотехнологію для сушіння фітоестрогенної рослинної сировини.

\section{References}

1. Boiko, O. O. (2013). Rozrobka stratehii rozvytku rynku soi v suchasnykh umovakh. Ahrosvit, 4,. $62-68$.

2. Drobot, V.B. (2001). Suchasnyi stan i perspektyvy vykorystannia produktiv pererobky soi u khlibopekarskii,makaronnii, kondyterskii ta kharchokontsentratnii promyslovosti. Naukovi pratsi, 21, 295 - 298.

3. Kapreliants, L.V. (2014). Soievi produkty ta inhrydiienty: khimiia, tekhnolohiia, vykorystannia. Kyiv: Monohrafiia, «TES», 194.

4. Zvit USDA. (2019) Ohliad rynku oliinykh kultur Retrieved from: https://agrex.gov.ua/zvit-usda-oglyadrinku-oliynih-kultur/

5. Metlytskyi, L. V. (1976). Osnovy byokhymyy plodov y ovoshchei. M.: Ekonomyka, 349.

6. Andreana, L. Ososki, Edward, J. Kennelly (2003) Phytoestrogens: a Review of the Present State of Research. Phytotherapy research. Phytother. Res., 17, 845-869.

7. Sniezhkin, Yu.F., Petrova, Zh.O. (2007) Teplomasoobminni protsesy pid chas oderzhannia karotynovmisnykh poroshkiv. Kyiv: VD «Akademperiodyka»,.162.

8. Jocelem Mastrodi Salgado, Carlos M. Donado-Pestana (2011). Soy as a Functional Food. Soybean and Nutrition. Rijeka, Croatia \& Shanghai, China, $21-44$.

9. Sniezhkin, Yu.F., Muliar, V.P., Dabizha, N.O. (2016). Analiz suchasnykh sposobiv sushinnia ta rozrobka optymalnoho rezhymu sushinnia koloidnykh kapiliarno-porystykh materialiv u teplonasosnii sushartsi $\mathrm{z}$ kombinovanym teplopidvodom. Keramyka: nauka y zhyzn, 30, 42-48.

10. Petrova, Zh.O., Slobodianiuk, K.S. (2016) Poperednia pidhotovka fitoestrohennoi syrovyny do sushinnia / Zbirnyk tez dopovidei KhI mizhnarodnoi naukovo - praktychnoi konferentsii studentiv, aspirantiv i molodykh vchenykh «Resursoenerhozberihaiuchi tekhnolohii ta obladnannia». K.: NTUU «KPI», 56 - 58.

11. Petrova, Zh.O., Slobodianiuk, K.S. (2017) Energy effective drying modes of soy-vegetable compositions // Ukrainian Journal of Food Science, 5(1), 150 - 160.

12. Voskoboinykov, V.A., Huliaev, V.N., Kats, Z.A., Popov, O.A. (1980). Sushenye ovoshchy y frukty. M.: Pyshchevaia prom-st,. 190.

13. Petrova, Zh.O., Slobodianiuk, K.S. (2017). Intensyfikatsiia protsesu sushinnia soievo-shpynatnoi kompozytsii. Materialy Kh Mizhnarodnoi naukovo-prakt. konf. «Problemy teplofizyky ta teploenerhetyky», Kyiv: ITTF NANU. El.resurs Retrieved from: http://ittf.kiev.ua/wp-content/uploads/2017/06/s3 tezi_18.pdf

14. Petrova, Zh.O. Slobodianiuk, K.S. (2017). Poluchenye neэnerhoemkykh fytoэstrohennykh rastytelnykh poroshkov. Scientific Works, 81(1), $110-114$.

15. Didora, V.H., Derebon, I.Iu. (2017) Tekhnolohichni pokaznyky yakosti lonu oliinoho zalezhno vid elementiv tekhnolohii vyroshchuvannia v umovakh polissia Ukrainy. Silske hospodarstvo ta lisivnytstvo. 1(6), 7179.

16. Petrova, Zh.O. (2013) Stvorennia enerhoefektyvnykh teplotekhnolohii vyrobnytstva funktsionalnykh kharchovykh poroshkiv: dys. ... dokt. tekhn. nauk : 05.14.06. Kyiv, ITTF NANU.

Отримано в редакцію 04.04.2019

Прийнято до друку 20.06.2019
Received 04.04.2019

Approved 20.06.2019 